\section{EFFECTIVENESS OF LUMBAR MANIPULATION (HIGH VELOCITY LOW AMPLITUDE) FOR THE TREATMENT OF LOW BACK PAIN IN COMPARISON TO BACK STRETCHING EXERCISES}

\section{ABSTRAC}

OBJECTIVES

To assess the effectiveness of lumbar manipulation (high velocity low amplitude) STUDY DESIGN

Randomized Control Trial (Experimental Study)

METHOD

The study was conducted on 200 patients at the Physiotherapy Department of acute or chronic origin. In this study, patients were divided into two groups. group A and group B equally. Group A of 100 patients received Lumbar Manipulation (High Velocity Low Amplifude) and at the same time Group B of 100 questionnaire was used to collect data. Data was entered and analyzed by using SPSS.

\section{OUTCOME MEASURES}

Pain was measured on Visual Analogue Scale before and after the given resurs

The study showed significant results for both the interventions in the treatment of . CONCLUSIONS

On the basis of this study, we are very confident that lumbar manipulation is more effective for the treatment of low back pain compared to back stretching exercise.

\section{INTRODUCTION}

Low back pain (LBP) refers to pain felt in the lower back. most of our body's weight Risk factors of developing $L$ B include old age, family history, pregnancy, compess rractures of the spine, back surgery, congenital deformity, prolong sitting, sedentary lifestyle, smoking, poor posture persisting for less than 6 weeks), sub acute LBP (i.e. persisting for 6 to 12 weeks) and chronic LBP (i.e. persisting or more than 12 weeks $)^{3}$. It has been proposed that LBP has a point prevalence of $6 \%$ to $33 \%$ and 1 -year preva rom $11 \%$ to $84 \% 47$. Hoy $D$ et al in their article regarding epidemiology of low back pain mentioned point preva ence range from $1.0 \%$ to $58.1 \%$ with a mean prevalence

The European Guidelines for Management of LBP effective first-line management for LBP. Exercise therap appears to be slightly effective in decreasing pain an in healthcare populations. In sub-acute IBP there evidence that a graded activity program improves

spinal manipulation is a safe intervention that is applied to patients with different types of low back pain. It can be defined as a localized or globally applied, single, quick ty thrust" of small amplitude, following careful positionit of the patient". The procedure is differentiated from mobilization in that a thrust is applied during the sechnique, versus low a vectivis ape ed in clinical practice guidelines for low back ain $^{13}$, wh evidence that exists to support the use of spinal manipulation for improvement of pain and function in patients with

spinal manipulative therapy is not only being used by physiotherapist but also by a number of other healthcare professions, such as chiropractors, osteopathic manipulation falls within their scope of clinical practice Although initially underutilized by physical therapists. momentum and adherence to evidence-based practice ent with the increased use in the clinic have been published contributions by physical therapists on the of these publications by other healthare profossions" Despite of all the research done so far yet not enough successful attempts have been made to effectively and comprehensively define outcomes associated with effectiveness of this intervention for patients with low back pain.

[Kazmi SAM, Faruq NM, Farooqui SI, of Lumbar Manipulation (High Velocity Low Amplitude) For the Treatment of Low Back Pain in Comparison to Back Stretching 2012:1(1):23-27]

The objective of this research was to analyze the the treatment of patients with LBP. Effectiveness was determined by analyzing studies that compared physica ecommed supervised exercise therapy as a very absenteeism outcomes, though evidence for other types physicians, and medical physicians. The use by physica

\section{OBJECTIVE OF THE STUDY}

To find the effectiveness of Lumbar Manipulation (HVLA) Stretching Exercises.

METHODOLOGY

Study Design

is a randomized control trial, experimental study Study Duration

the study has been conducted in duration of one year.

Sampling Method

A sample size of 200 patients was calculated through Epi With a point prevelance $18.1 \%$ at $95 \%$ confidence level study equally divided into two groups. Group A: 100 patients were given Lumbar Manipulation.

\section{Study Setting}

partment of Ziauddin Hospital, Karachi, Pakistan.

\section{Data Collecting Procedure}

The study is being conducted on the 200 patients includingale and female, with age range of 18-65 years. All consent was sought from the subject before participating the study, thereafter; the subjects were randomly divided into two groups, Group A and Group B, each
consisting of 100 patients. Both groups received same poecol of treatment, including hot pack and Trans(a) Pain intensity was examined by a visual analogue scale (VAS) both pre-treatment and post-treatment which was recorde on pre tested and structured for the collection of data Data was analyzed on SPSS version 20 .

Inclusion Criteria

(6) were included in this study.

Exclusion Criteria

Patients with history of Spinal fracture, Neurologic signs Pregnancy. Post surgical were not included in the study.

Ethical Consideration

According to ethical consideration Patient privacy, Environment of the place where we treat the patient were given due importance.

\section{RESULTS} therapy spinal manipulations with stretching exercises.
This study shows analysis of both treatment protocols
given to a sample of 200 patients suffering from Low Back Pain where group A consisting of 100 patients was given given back stretching exercises for the pain manoge years. Out of 200 patients, $52.5 \%$ were male while $47.5 \%$ ment. Mean age of the total sample was $37.67+9.56$ 


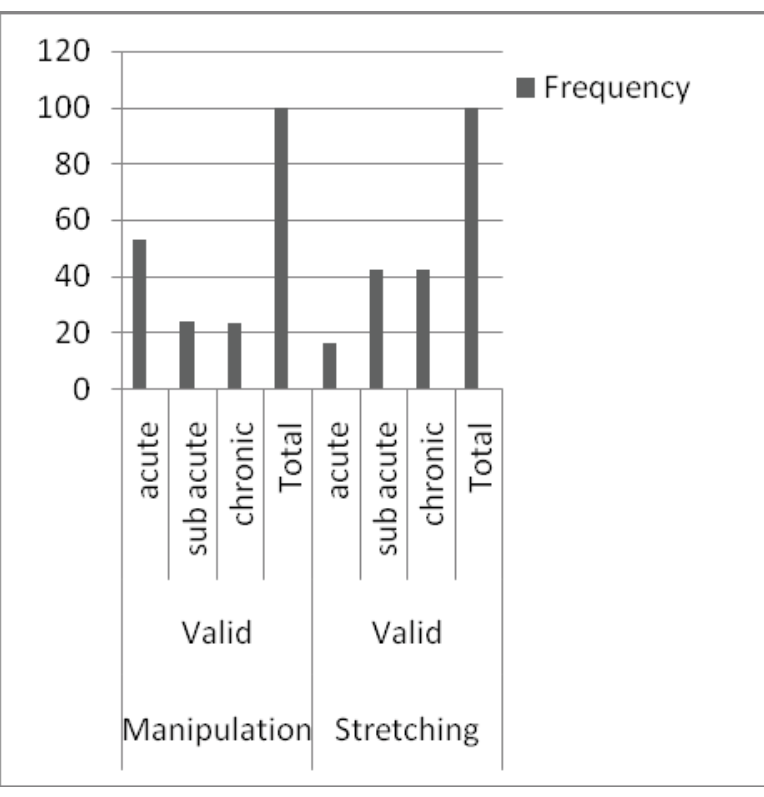

Types of Low Back Pain

females. Out of 100 patients of Group A, who were given pain while 24 were sub acute and 23 chronic was seen that 16 patients were of acute origin and 42 each of sub acute and chronic low back pain.

Table 1: Intensity of Pain (Before and After Treatment)

\begin{tabular}{|l|l|c|c|}
\hline \multicolumn{2}{|c|}{} & $\begin{array}{c}\text { Intensity of } \\
\text { Pain on } \\
\text { VAS Scale } \\
\text { before } \\
\text { Treatment }\end{array}$ & $\begin{array}{c}\text { Intensity of } \\
\text { Pain on VAS } \\
\text { Scale after } \\
\text { Treatment }\end{array}$ \\
\hline Manipulation & N & 100 & 100 \\
\cline { 2 - 4 } & Mean & 6.15 & 1.19 \\
\cline { 2 - 4 } & $\begin{array}{l}\text { Std. } \\
\text { Deviation }\end{array}$ & 1.009 & .813 \\
\hline Stretching & N & 100 & 100 \\
\cline { 2 - 4 } & Mean & 5.89 & 2.31 \\
\cline { 2 - 4 } & $\begin{array}{l}\text { Std. } \\
\text { Deviation }\end{array}$ & .898 & .873 \\
\hline Total & N & 200 & 200 \\
\cline { 2 - 4 } & Mean & 6.02 & 1.75 \\
\cline { 2 - 4 } & $\begin{array}{l}\text { Std. } \\
\text { Deviation }\end{array}$ & .961 & 1.011 \\
\hline
\end{tabular}

Intensity of pain was measured on VAS Scale before and
after treatments. It was observed that mean intensity of pain in patients of Group A was $6.15 \pm 1.009$ and after the reatment it was reduced to $1.19 \pm 0.813$. While in Group intensity of pain on VAS Scale before the treatment was
$5.89 \pm 0.898$ and after treatment it was reduced to only $2.31 \pm 0.873$ (Table 1)

The data was analyzed to find out the effectiveness of exercises for the management of low back pain. Paired
Sample test was applied to found the effectiveness of these interventions and it was seen that both are

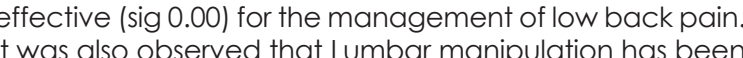
more effective in all types of low back pain including acute, sub acute and chronic LBP (Table 2).

Table 2: Mean Intensity of Pain in Different Types of LBP

\begin{tabular}{|c|c|c|}
\hline Type of LBP & $\begin{array}{c}\text { Mean } \\
\text { Intensity of } \\
\text { Pain on VAS } \\
\text { Scale before } \\
\text { Treatment }\end{array}$ & $\begin{array}{c}\text { Mean } \\
\text { Intensity of } \\
\text { Pain on VAS } \\
\text { Scale after } \\
\text { Treatment }\end{array}$ \\
\hline $\begin{array}{c}\text { Acute } \\
\text { Manipulation } \\
\text { Stretching }\end{array}$ & 6.06 & 1.19 \\
\hline Sub Acute & 6.00 & 2.19 \\
Manipulation & 6.04 & 1.21 \\
Stretching & 5.62 & 2.31 \\
\hline $\begin{array}{c}\text { Chronic } \\
\text { Manipulation } \\
\text { Stretching }\end{array}$ & 6.48 & 1.17 \\
\hline
\end{tabular}

Mean intensities on VAS Scale before and affer the given interventions evidently show that there is remarkable low back pain compared to back stretching exercises of Acute LBP, intensity of pain 6.06 before Lumbar manipulation and was reduced to 1.19 while in Sub acute LBP, pain intensity was 6.04 earlier and 1.21 anter lumbar manipulation. In chronic patients of LBP, pain intensity was 6.48
before the said treatment and 1.17 after manipulation On the other hand stretching exercises have shown less effectiveness on VAS scale.

Table 3: Comparison of Manipulation and stretching

\begin{tabular}{|c|c|c|c|}
\hline Group & $\begin{array}{c}\text { Mean } \\
\pm \text { SD }\end{array}$ & $\mathrm{t}$ & $\begin{array}{c}\text { Sig. (2- } \\
\text { tailed) }\end{array}$ \\
\hline Manipulation & $\begin{array}{c}4.96 \pm \\
1.23\end{array}$ & 40.31 & 0.00 \\
\hline $\begin{array}{c}\text { Stretching } \\
\text { Exercise }\end{array}$ & $\begin{array}{c}3.58 \pm \\
1.23\end{array}$ & 29.04 & 0.00 \\
\hline
\end{tabular}

This study has found that Lumbar Manipulation (HVLA) and back stretching exercises are effective in the lumbar manipulation (HVLA) has shown to be more effectivivin management of LBP of all types on the basis
of VAS Scale.

\section{DISCUSSION}

All the patients in this study were between the age group sinal fracture neurologic signs and symptoms progn

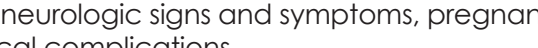

In our study, the patient's response to specific treatmen felt relief in pain after the given treatment but there was prominent reduction in pain in patients who underwen manipulation compared to stretching exercises.

According to Evans et al. manipulation is beneficial in educing low back pain but for a shorter period ${ }^{18}$. It was results in patients with acute low back pain.

In another article by Koppenhaver $S L$ et al stated that if patient has LBP that is fairly acute without any focal and Iritable symptoms, may be the best candidates Spina
Manipulative Therapy treatment approach's? In our study we had similar patients and the Manipulative therapy has been extremely effective as a treatment option.

According to Bronfort $G$ et al suprvised exercise was more significant for the management of chronic low back pain compared to tudy stretching exercise was seen to be slight way, effective in management of low back pain of chronic origin.

Other treatment options for managing low back pain to patients for home. These exercises might be effective exercises show immediate results which might be for exercises show immediate results which might be for Manipulative Therapy is effective for the treatment of chronic nonspecific LBP. Researches also suggest tha
lumbar manipulation may be extremely effective to obtain long-term benefit, after the initial intensive manipulative therapy ${ }^{12} 24$

Rubinstein S. et al suggests that High- quality evidence is between SMT and other interventions for reducing pain and improving function in patients with chronic low-bac

In my experience, spinal manipulation has been more has shown better results in chronic low back pain.

\section{CONCLUSION}

We are $95 \%$ confident that the effectiveness of lumbar manipulation (high velocity low amplitude) for the reatment of low back pain is not equal to stretching we could suggest that the lumbar manipulation management of low back pain.

\section{REFERENCE}

1] Black KM, Korn H, Nordin M. Association between 2007:16(2):283-298

Ehrich G E. Bulletin of the WHO 2003:8:671-676.

van Tudler M, Becker A, Bekkering T, Breen A, Gil de Real M, Hutchinson A et al: Chapter 3 European guidelines for the an Spine J. 2006; 15: s169-5191.

[4] Dagenais $S$, Gay RE, Tricco AC. NASS contemporary concepts in spine care: spinal manipulation therapy RAB, Ostelo RWJG, Thomassen JMC, van Tulder MW: Dutch Physiotherapy Guidelines for Low Back Pain.

Dusch Physo herapy 2003

Exercise therapy for treatment of non-s, Koesific BW: back pain. Cochrane Database Syst Rev 2005, (3) Hoy D, Brooks P, Bly ha , Buchbinder R. The

8] Pengel LH, Herbert RD, Maher CG, Reishauge KM: Acute low back pain: systematic review of its

19] Walker BF. The prevalence of low back pain: a Wystematic review of the literature from 1966 to 1998. J Spinal Disord. 2000;13:205-17.

[10] Airaksinen O, Brox Jl, Cedraschi C, et al. European nonsecific low back pain. Eur Spine J. 2004,15

[11] Sizer PS, Felstehausen V, Sawyer S. Eight critical skill sets required for manual therapy competency: a educators of manual therapy, I Allied Health 2007:36(1):30-40. 12] Mintken PE, Derosa C, Little T. American Academy
of Orthopaedic Manual Physical Therapists. J Man Manip Ther. 2008:16:50-6.

[13] Chou R, Huffman LH. American Pain Society. American College of Physicians Non-pharmacologreview of the evidence for an American Pain Socictice college of Physicians clinical 2007:1 147(7):492-504.

[14] Woodhead I, Clough A. A systematic review of the evidence for manipulation in the treatment of low

15] Huiibregts PA. Chiropractic legal challenges to the physical therapy scope of practice: anybody else taking the ethical high ground. I Man Manip Ther.

[16] Flynn TW, Wainner RS, Fritz JM. Spinal manipulation in physical therapist professional degree education: a
model for teachion practice. I Orthop Sports Phys Ther.

17] Meeker W. Wake up: We're in a race for scientific ownership of manipulation. FCER Advance. 2005;25(1):1-13.
Evans DP, Burke MS, Lloyd KN, Roberts EE, Roberts GM. Lumbar Spinal Manipulation on Trial. Part 1 1 Clinical assesment. Rheumatol Rehabil.
1978;17:46-53.

[19] Koppenhaver SL, Fritz JM, Hebert JJ, Kawchuk GN,
Parent EC, Gill NW, Childs JD, Teyhen DS. examination factors and change in lumbar 
multifidus muscle thickness after spinal manipulation mitients with low back pain. I Electromyography

[20] Bronfort G, Maiers MJ, Evans RL, Schulz CA, Bracha TA, Transfeldt EE. Supervised exercise, spina manipulation, and home exercise for chronic low back pain: a randomized clinical trial Spine

Kachaly, Shereen A. Does Maintained Spinal Manipulation Therapy for Long-Term Outcome? I Spine; 15 Augus Therapy for Chronic Low-Back Pain: An Update of
Cochrane Review. Spine 2011:36(13): E825-E846. Brontort G, Goldsminh CH, Nelson CF, et al. Trunk exercise combined with spinal manipulative and Manipulative Physiol Ther 1996:19:570-82.

[24] Ernst E, Canter PH. A systematic review of systematic reviews of spinal manipulation. I R Soc Med

[25] Rubinstein SM, van Middelkoop M, Assendelft WJJ, low-back pain. Cochrane Database of Sys 26] Rev.2011; 2 poin.

政 curricula in physical therapy professional degree programs. J
2004:34:4171-81.

\section{THE ASSOCIATION OF SITTING POSTURE AND CERVICOGENIC PAIN AMONG THE STUDENTS OF PHYSICAL THERAPY}

\section{ABSTRACT}

OBJECTIVE

To determine the prevalence and association of cervicogenic pain and poor sitting posture among the students of Physical Therapy.

METHOD

A cross sectional survey was conducted among the students through conven A dath Both descriptive and interference statistics were used to analyzed the

\section{STUDY DESIGN}

A cross- sectional study design was selected for this study.

STUDY SETTINGS \& PARTICIPANTS

students $(n=100)$ has been selected from the different private and government

RESULTS

From the sample size ( $n=100$ ) including students of Physical Therapy, had

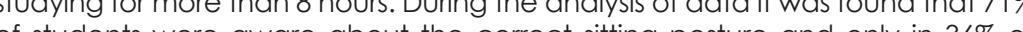
of CONCLUSION

the result of the study shows that the prevalence of cervicogenic pain is higher there were other associated factors too. Maximum numbers of students were Among entire population ratio of pain was higher in female than male students.
Navaid-us-Saba

Ziauddin College of Physical Therapy

Amna Aamir Khan Senior Lecturer

Ziauddin College of Physical Therapy akhan39@caledonain.ac.uk

Summaira Imran Farooqu Department of Physical Therapy Principal

Ziauddin College of Physical Therapy Ziauddin University

Zara Omar

Institute of Business Management

zara_omar10@hotmail.com 